\title{
The Development and Application of Health Promotion and Education in Islamic Communities
}

DOI: http://dx.doi.org/10.5915/22-2-13557

\author{
Ahmed A. Moen, Dr. P.H., M.P.H., M.H.A., \\ Washington, D.C.
}

\begin{abstract}
The 1978 Declaration of Alma-Ata recognizes that primary health care and health for all by the year 2000, must evolve from and reflect the economic conditions and the sociocultural and political characteristics of the country and its communities. Given the proper knowledge, skills, and attitudes, Islam-oriented health educators and promoters who apprecicate the Qur'ānic teachings and Prophetic Medicine and Practices can serve better as modern agents for change in Muslim communities. They can easily, mediate social changes and facilitate behavioral modifications, and can adapt, transfer and adopt traditional teachings into modern primary health care.
\end{abstract}

Key words: Al-țahārah, al-taqwā, al-nagāahah, Ummah, Ijmā'; Hadīth, Sunnah

The 1978 Declaration of Alma-Ata recognizes that primary health care and "health for all by the year 2000 ," must evolve from and reflect the economic conditions and the socio-cultural and political characteristics of the country and its communities.' However, since then most of the publications and research on primary health care and health for all seem to have focused on the importance of political and socio-economic environment of health planning, managing and evaluation of modern health services.

Although there is no overt attempt to minimize the viability of the Islamic concepts of health, wellness and community social and political organizations ("Ummah"), the ministries of health and community development in many Muslim countries have favored

From the Health Services Administration and International Health, Department of the Health Services Administration School of Business and Public Administration, Howard University, Washington, D.C. 20059

Reprint Requests:

Ahmed A. Moen, Dr. P.H., M.P.H., M.H.A.

Health Services Administration and

International Health Department

Health Services Administration

School of Business and Public Administration

Howard University

Washington, D.C. 20059
Western expertise, educational curricula, technologies, and organization patterns. This approach to a certain degree seems to have created a socio-cultural gap between modern organization and the traditional grass-root community organization ("Ummah"). Much of this gap stems partly from under-utilization of indigenous ideas, resources and expertise, ineffective performance of modern health services, under-representation of Islamic public health concepts in university-based professional education, and lack of community support and participation which are the first line of defence in health promotion. This article will attempt to discuss the concepts and application of Islamic health values, beliefs, and practices in designing health education and promotion strategies for primary health care and health for all.

\section{Background}

At the outset of the "health for all by the year 2000 " movement, most of the ministries of health in the developing countries, as well as international bilateral and multilateral organizations, were enthused by the successful mass organization and management style of smallpox eradication programs. Nevertheless, many health policy-makers recognized that unlike smallpox eradication, which is based on a single shot vaccination and mass mobilization for a 
unique cause, primary health care demands sustained and long-term health and behavioral modifications. It requires among other things, viable grass-roots organizations and sustainable health education strategies based on indigenous values, beliefs and practices which are amenable to integration with the formal medical delivery systems. This means that medical and health care services must be adaptable, acceptable, available and accessible to the community.

Basically, those who accept the concept of community-based primary health care systems believe in equity and social justice. They also believe that health for all is an overdue debt to be paid to the disenfranchised poor and rural population who have been denied access to modern health care services. This limited access to modern health services has been worsened by the fact that some of the urbantrained modern health professionals who subseuently practice in rural settings have been inadequately prepared to manage the complex social dynamics that inhibit equal interactions between orthodox medicine and the prevalent traditional healings. ${ }^{2}$ In view of this cultural contradiction, two separate health service tracks has been developed: one for the selective "urban elite" benefitting from the sophisticated medical technology, and the other for the "traditional rural" majority deprived of the modern primary health care.

In the past decade, two strategies evolved to expedite "health for all by the year 2000 ." The first is re-structuring the primary health care delivery system, and the second is integrating Western technology with selective components of traditional healing practices. Re-structuring primary health care cannotes mobilizing indigenous know-how, modifying the practice behaviors of the providers and users of primary health care, and re-designing some aspects of the medical and public health curricula. With this assumption in mind, we will attempt to examine how the Islamic concept of health promotion and education was developed and how it can play an effective role in behavioral modification within the existing primary health care delivery systems, particularly in Muslim communities.

\section{Health and illness: an Islamic perspective}

Most of the traditional healing and health education in Islam have evolved from the Prophetic Medicine "Al-tibb al-nabawi". The Prophetic Medicine consists of the Qur'anic teachings, the sayings "Ahadith" and practices "Sunnah" of Prophet Muhammad (PBUH). Health and illness are perceived at three different levels. ${ }^{3}$ The first one relates to the suspicious state of mind. For example, the Qur'ān says:

"There is a disease in their hearts, so Allāh added to their disease . . . ${ }_{4}$

"Is there in their hearts a disease, or are they in doubt? ....",s

The second refers to presence of physical disease and infirmity. In two separate references, the Qur'ān says:

"There is no blame on the blind man, nor is there blame on the lame, nor is there blame on the sick ...." ",6,7

The third refers to the interdependence between the divine and man. This is well manifested by the Prophet Ibrāhim who depended on Allāh (SWT) to satisfy his basic health and human needs. The Qur'ān says:

"And $\mathrm{He}$ Who gives me to eat and gives me to drink; And when I am sick, then He restores me to health; And $\mathrm{He}$ Who will cause me to die, then give me life."

Notwithstanding this wider sense of health and ilIness, the Qur'ān attaches primary importance to physical well-being in performing pilgrimages (Hajj) and in fasting (Ramaḍān):

" . . . But whoever among you is sick or has an ailment of the head (during pilgrimage), he should compensate by fasting or giving alms or sacrifice ..." "s

"... But whoever among you is sick or on a journey (during Ramadān), then he shall compensate for (by fasting) in other days. Allāh desires ease for you . . ." "10

There are also several "'Ahadith" quoted below which compliment the notion of comprehensive primary health care, that is, health maintenance, disease prevention, sanitation and personal hygiene. The Prophet Muhammad (PBUH), for example, exhorts his followers to seek treatment for illness. In Sunan al-Tarmadhi, 'Usāmah Bin Shark reported that the Prophet (PBUH) said:

"I was with the Prophet (PBUH) when some Arabs came and asked: 'Oh messenger of Allāh! Do we take medicine for treatment? He replied: 'Yes, oh you the servants of Allāh, take medicine, as Allāh Almighty never inflicts a disease without providing a cure for it, except one disease.' They asked him. 'What is it?' He replied: 'Old age!'","

In another version according to Ibn-Mājah, the Prophet (PBUH) considers that knowledge about disease prevention is as important as its cure:

"Allāh never inflicts a disease without providing a cure; only those who were aware of it knew it, whereas those who were unaware were ignorant of 
it". ${ }^{12}$

There are also two other concepts of prevention that have contributed to the widespread practice of public health education and promotion beyond their religious significance, that is, "al-wiqāyah" and "altahärah".

First of all, "al-wiqāyah" comes from that same root as "al-taqwā". The root word is "wqy" which means "piety", "to fear God", "to protect from being lost or wasted", "to guard against peril", ${ }^{13}$ or "to restrain". Irrespective of these various shades of meaning and interpretation, "protection from being lost or wasted", "guarding against peril" and "restraining" seem to be central to the subsequent discussion of disease prevention.

Second, the notion of "al-tahārah", which means purity from moral or physical defilement, is pervasive in the Qur'ān, "Ahadith",', and "Fiqh-ulSunnah."'s The latter, Figh-ul-Sunnah, embodies the definition and standards of purity and its application. According to Figh-ul-Sunnah, occurrence of tangible impurity requires removal of defilement "alnajāsah" from body, place, clothes or utensils by clean water or its equivalent. The quantity of water must meet defined standards that makes it useful for human consumption. It must also be free from biologic and physical intruders such as visible polluting substances, free from alteration in its physical properties and stagnation (i.e., color, smell, or test). ${ }^{16}$

'Abu Hurayrah, for example, reported that the Messenger of Allāh forbade urinating in stagnant water. The Prophet (PBUH) said:

"None amongst you should urinate in standing water, and then wash in it." "7

The standards of purity can be extrapolated into other areas of health. Thus, the presence of pollutants in water, in mixed soft drinks, and in food can also negate the worthiness of their consumption. ${ }^{18}$

Finally, our subsequent discussion of the Islamic strategies of health education and promotion evolves from the foregoing concepts of health and illness. These concepts, by and large, define and shape health behavior, beliefs, and practices in Muslim communities.

\section{Health education: concepts and role models}

Health educators can play an important role in social changes. They can link the Islamic concepts of purity "al-țahärah" and prevention "al-wiqāyah" derived from "al-taqwā" to health behavior and practices pertaining to the consumption, handling and processing of food, disease prevention, personal hygiene and environmental sanitation. Pertinent lessons can be taken from the Qur'ān and "'Ahadith" and from the life and practices "Sunnah" of the Prophet (PBUH). The Prophet (PBUH) has been a role model and an educator who sets moral, social and health standards, and a person who preaches and practices moderation and self-restraint. The Qur'ān sums his life style and teachings as follows:

" ... For he (the Prophet) commands them what is just and forbids them what is evil; he allows them as lawful what is good (and pure) and prohibits them from what is impure ..." ",

Moreover, the Prophet (PBUH) as a communicator, understood the causes and effects of behavioral changes. He employed effective educational strategies to promote and reward positive behavior, and prevent negative ones by giving mundane examples relevant to human nature, health and the social environment. In this respect, Bukhäri and Muslim reported that the Prophet (PBUH) said:

"When you wake up from sleep, do not immerse the hands in a vessel (utensils) until you have washed them three times: for no one knows where the hands have strayed during the night." 20

"When a dog licks the content of a vessel (utensils) belonging to anyone of you; the vessel must be washed (cleansed) seven times, using clean soil (sand) the first time." ${ }^{21}$

The soil or sand in this instance is equivalent to detergent to wash off the contaminated wet saliva.

In linking personal hygiene with environmental sanitation, the Prophet (PBUH) said:

"The deeds of my nation were presented to me. I found amongst the best, the removal of dirt from the road and I found amongst the worst, the mucus (spit) in the mosque for it is not buried.", 22

The Prophet (PBUH), moreover, valued privacy and public decency. He said:

"Those who void excrement in people's roads and shades are those who are cursed by people."'23

In his life, the Prophet (PBUH), as a role model, has practiced and set standards of purity by adhering to the Qur'anic commandments revealed to him:

“Purify your raiment (clothes).", 24

Thus, the Prophet as an educator and role model was able to discourage negative health behavior such as voiding and spitting in public, and at the same time, he praised positive practices such as removing dirt, decontaminating and washing utensils, and purifying oneself.

Notwithstanding the existence of these high standards and traditions of public health education in Islam, the question very often asked is how some ordinary Muslims, who believe and practice purity, could be insensitive to modern health education and the principles of disease prevention? How could Muslims allow their food and utensils to be con- 
taminated by germ carriers such as the common fly which frequently rests on feces or dirt, in spite of the preceding statements and examples from the life of the Prophet (PBUH)? How could they drink from and wash in unprotected wells and polluted, stagnant ponds and rivers? The answer to all these questions seems to lie in the absence of logical connections between modern health education and culturally accepted Islamic health beliefs and practices. If sufficient linkages between Islamic health beliefs and practices, and modern public health education can be established during the formative age and adulthood, it will be possible to impress on ordinary Muslims that food becomes impure or polluted "najas" by mere contact with the germ carrier, such as the common fly. Every Muslim is aware that feces and urine in any form or shape are considered pollutants "najãsah". If Western trained health educators develop cultural sensitivity towards Islamic health standards and educational strategies, they can play effective roles in inducing compatible behavioral changes, as did the Prophet Muhammad (PBUH).

This author's experience in designing and reviewing health education and community development programs shows that it is easier to teach villagers to adhere to modern public health education practices that are compatible with the Islamic concepts of public health. It has been observed that learning the chapter on purification "al-țahärah" in Fiqh-ulSunnah, for example, has great significance and acceptability in shaping villagers' health attitudes, beliefs, and practices. The theoretical principles of personal hygiene and sanitation offered in the Book of Purification and Prayer" in "Fiqh-ul-Sunnah" is equivalent to the introductory courses in modern texts of public health. As a matter of fact, the operative procedures of ablution "wudū", and ceremonial bathing "ghusl", which are taken for granted by the majority of Muslims, are so comprehensive as to cover physical hygiene from head to toe, including oral hygiene, human waste and privy etiquettes, as well as dressing manners.

The institutionalization of these Islamic concepts in higher learning curricula would, indeed, enhance the main body of knowledge and armamentaria in the arnsenal of modern primary health care and public health. These Islamic concepts, values, and practices need to be integrated into public health and rural development curricula of Western higher learning institutions as well as in on-the-job training of international health and community development consultants. They would, moreover, develop new competencies, awareness and sensitivity that would enable the new breed of agents for change and health practitioners to gain acceptance and credibility in Muslim communities.

Having said that, it should be recognized that the teaching of Islamic concepts of public health emobodied in the Qur'ān and Prophetic Medicine does not preclude imparting scientific concepts of modern public health, the value of sterilization techniques, and the application of prophylaxis, immunization or chemotherapy in the prevention and cure of diseases. On the contrary, the new emphasis should be on the convergence and compatibility of acceptable Islamic health values and cultural practices with the basic principles of modern public health. Moreover, in order to maximize the relative advantages of modern public health education and social marketing techniques developed from experimental biomedical research and scientific medicine, and social sciences, they should be simplified and adapted to the needs of the ordinary people. Otherwise, making ordinary people understand and accept the scientific values of modern primary health care per se will remain a difficult task to achieve, and may be an unaffordable proposition, beyond the reach of the tradition and thinking process of ordinary people, particularly those burdened by poverty, ignorance and disease.

\section{Health promotion, the Qur'anic stragety}

Muslim social scientists agree that the Qur'ānic strategy continues to be viable, and that it can serve as an outstanding model applicable to engineering gradual social changes and health promotion in Muslim communities. The strategy of self-protection "al-taqwā" is a unique tool in promoting disease prevention, social and behavioral modification. It seeks, among other things, to reward better behavior and practices through motivation and persuasion.

The Qur'ānic strategy employed to prohibit drinking and gambling, for example, demonstrates the applicability of the Islamic logical framework, its scientific thinking process, and argument from problem identification to its solution:

Stage 1: Identification of the problem: The Qur'ān says:

"They ask you about intoxicants and games of chance. Say: In both of them there is a great sin and means of profit (benefit) for men, and their sin (demerits) is greater than their profit." 25

Stage 2: Development of the solution: The Qur'ān says:

"Oh you who believe! Intoxicants and games of chance and sacrificing to stone images and arrows are only an uncleanness, the "Shayțān's" (Satan's) work; shun it therefore that you may be successful." 26

Stage 3: Implementation of change:

The Qur'ān says: 
"The Shaytän (Satan) only desires to cause enmity and hatred to spring in your midst by means of intoxicants and games of chance, and to keep you off from the rememberance of Allăh and from prayer. Will you then desist?"'27

By the same token, the Qur'ān teaches Muslims to exercise self-restraint and lead moderate life-styles. Thus, Muslim health practitioners more than any other group recognize that modern disease prevention and health promotion strategies that prevent alcohol, smoking, substance abuse, excessive eating and environmental pollution are worthwhile and compatible with Islamic life-styles, health beliefs, values and practices.

\section{The Qur'ān says:}

". . . and eat and drink and be not extravagent: Surely He does not love the extravagent."'28

Finally, given this common body of knowledge, as well as the skills of problem identification and solution stated above, health educators can motivate Muslim communities to adhere to Qur'ānic health guidance, to contemplate its meanings and to benefit from its pragmatic and up-to-date teachings. In its didactive teachings, moreover, the Qur'ān inspires people to seek better changes and aspire for perfection by their own free will, through self-examination, choice and commitment, rather than by blind acceptance.

\section{The Qur'ān says:}

"This is because Allāh has never changed a favor which $\mathrm{He}$ has conferred upon a people until they changed their own condition; and Allāh is all Hearing, all Knowing." 29

"And By the soul and Him Who made it perfect. Then $\mathrm{He}$ inspired it to understand what is right and wrong for it." 30

\section{Conclusion}

In summary, achieving primary health care and "health for all by the year 2000" in Muslim communities requires the incorporation of Islamic reasoning and thinking processes in designing health maintenance, disease prevention, environmental and personal hygiene. Given the right training and attitude, health promoters and educators who appreciate Islamic health beliefs, values and practices embodied in the Qur'än and Prophetic Medicine can serve as modern agents of change. They can mediate social changes and facilitate behavioral modifications. They can also initiate, adapt, and transfer hybrid primary health care beliefs and practices to their constituencies. Their participation and collaboration in planning and executing health and development assistance projects alongside with their
Western trained development experts will not only enhance total wellness, but also will produce effective and acceptable results, which will accelerate the achievement of primary health care and "health for all by the year 2000 ."

\section{References}

1. World Health Organization, Alma-Ata Primary Health Care, Report of the International Conference on Primary Health Care, Alma-Ata, USSR, September 6-12, 1976, p 1.

2. Ojanua D N: What doctors think of traditional healers and vice versa. World Health Forum 1981, 2(3): 408.

3. Al-Azhari A, Al-Oqdah F M: Al-tibb-al-nabawi. (In Arabic) Dār-Al-Wifāq Publications, Beirut (No Date), p 2.

4. The Glorious Qur'ān Chapter 2, Verse 10.

5. The Glorious Qur'ān Chapter 24, Verse 50.

6. The Glorious Qur'än Chapter 24, Verse 61.

7. The Glorious Qur'ān Chapter 48, Verse 17.

8. The Glorious Qur'ān Chapter 26, Verses 79-81.

9. The Glorious Qur'ān Chapter 2, Verse 196.

10. The Glorious Qur'ān Chapter 11, Verse 185.

11. Al-Tarmadhi, (8th Century A.D.): Sunan alTarmadhi. (In Arabic) Dār Al-Fikr Publications, Beirut, 1983, Volume III:2109.

12. Ibn-Mājah (8th Century A.D.): Sunan IbnMājah. (In Arabic) Dar Al-Fikr Publications, Beirut, Volume II:3436.

13. Fazlur R: Health and Medicine in the Islamic Tradition. The Crossroad Publishing Company, 1981, p 13.

14. Al-Soliman T M: Environmental purity and cleanliness: An Islamic perspective. JIMA 1987, 19:100-105.

15. Sabiq, al-Sayyid, Fiqh-ul-Sunnah: Purification and Prayer. Translated by Muhammad Saeed Dabas, Jamal al-Din M. Zarabozo, American Trust Publications, 1985, p 6.

17. Muslim (8th Century A.D.): Sahih Muslim. Translated by Abdul Hamid Siddiqi, Sh. Muhammad Ashraf Publications. Kashmiri Bazar, Lahore, Pakistan, 1973, Volume I:554.

18. Al-Soliman, Ibid.

19. The Glorious Qur'ān Chapter 74, Verse 4

20. Sahih Muslim; Volume I:541.

21. Sahị Muslim; Volume I:549.

22. Wanli K: al Masjid Fi'l-Isläm (The Mosque in Islam), al-Salafiah, Kuwait, 1980, p 110, quoted in Al-Soliman: JIMA 1987; 19:100-105.

23. Sahih Muslim; Volume I:516.

24. The Glorious Qur'ān Chapter 74, Verse 4.

25. The Glorious Qur'än Chapter 2, Verse 219.

26. The Glorious Qur'ān Chapter 5, Verse 90.

27. The Glorious Qur'ān Chapter 5, Verse 91.

28. The Glorious Qur'ān Chapter 7, Verse 31.

29. The Glorious Qur'ān Chapter 8, Verse 53.

30. The Glorious Qur'ān Chapter 91, Verses 7-8. 